\title{
Da imagem que (me) falava: o retrato de minha avó materna.
}

\section{De la imagen que (me) hablaba: el retrato de mi abuela materna. Of the image that spoken (me): the portrait of my maternal grandmother.}

\author{
Paulo Emilio Macedo Pinto \\ Universidade de Pernambuco \\ Secretaria de Educação do Estado de Pernambuco \\ Coletivo Tuia de Artifícios \\ $\mathrm{CNPq}$ \\ paulo.emilio@upe.br
}

Recibido 13/12/2018

Aceptado 11/06/2019

Revisado 11/06/2019

\section{Resumo: \\ Esta escrita autobiográfica trata de minhas memórias afetivas despertadas pela fotografia de minha avó materna. A imagem é abraçada como um dispositivo para construir os trajetos de uma pessoa que nunca conheci pessoalmente. A imagem, os diálogos que ela sugere, através daqueles que testemunharam a existência corpórea de minha avó, ajuda- me a refletir sobre minhas heranças criativas, meu modo de sentir e tocar o mundo.}

\section{Resumen:}

Esta escritura autobiográfica trata con mis memorias afectivas despertadas por la fotografía de mi abuela materna. La imagen se adopta como un dispositivo para construir los caminos de una persona que nunca he encontrado personalmente. La imagen, los diálogos que ella sugiere, a través de aquellos que testimoniaron la existencia corpórea de mi abuela, me ayudan a reflexionar sobre mis herencias creativas, mi manera de sentir y tocar el mundo.

\section{Abstract: \\ This autobiographical writing deals with my affectionate memories awakened by the photograph of my maternal grandmother. The image is adopted as a device to build the paths of a person that I have never met in person. The image, the dialogues that she suggests, through those who have witnessed my grandmother's bodily existence, help me to reflect on my creative heritages, my way of feeling and touching the world.}


Da imagem que (me) falava: o retrato de minha avó materna. De la imagen que (me) hablaba: el retrato de mi abuela materna. Of the image that spoken (me): the portrait of my maternal grandmother.

https://dx.doi.org/10.17561/rtc.n16.2

Palavras-chave: Retrato. Avó. Memória. Fotobiografía. Afetividade. Criatividade. Herança.

Palabras clave: Retrato. Abuela. La memoria. Fotobiografía. La afectividad. La creatividad. Herencia.

Key words: Portrait. Grandmother. Memory. Photobiography. Affectivity. Creativity. Heritage.

Sugerencias para citar este artículo

Macedo Pinto, Paulo Emilio (2019). Da imagem que (me) falava: o retrato de minha avó materna. Tercio Creciente, 16, págs. 31-46. https://dx.doi.org/10.17561/rtc.n16.2

MACEDO PINTO, PAULO EMILIO. Da imagem que (me) falava: o retrato de minha avó materna. Tercio Creciente, julio 2019. $n^{\circ} 16$, pp. 31-46. https://dx.doi.org/10.17561/rtc.n16.2 
ISSN: $2340-9096$

https://dx.doi.org/10.17561/rtc.
Revista de Estudios en Sociedad, Artes y Gestión Cultural

Número 16

Julio 2020

http://revistaselectronicas.ujaen.es/index.php/RTC

www.terciocreciente.com

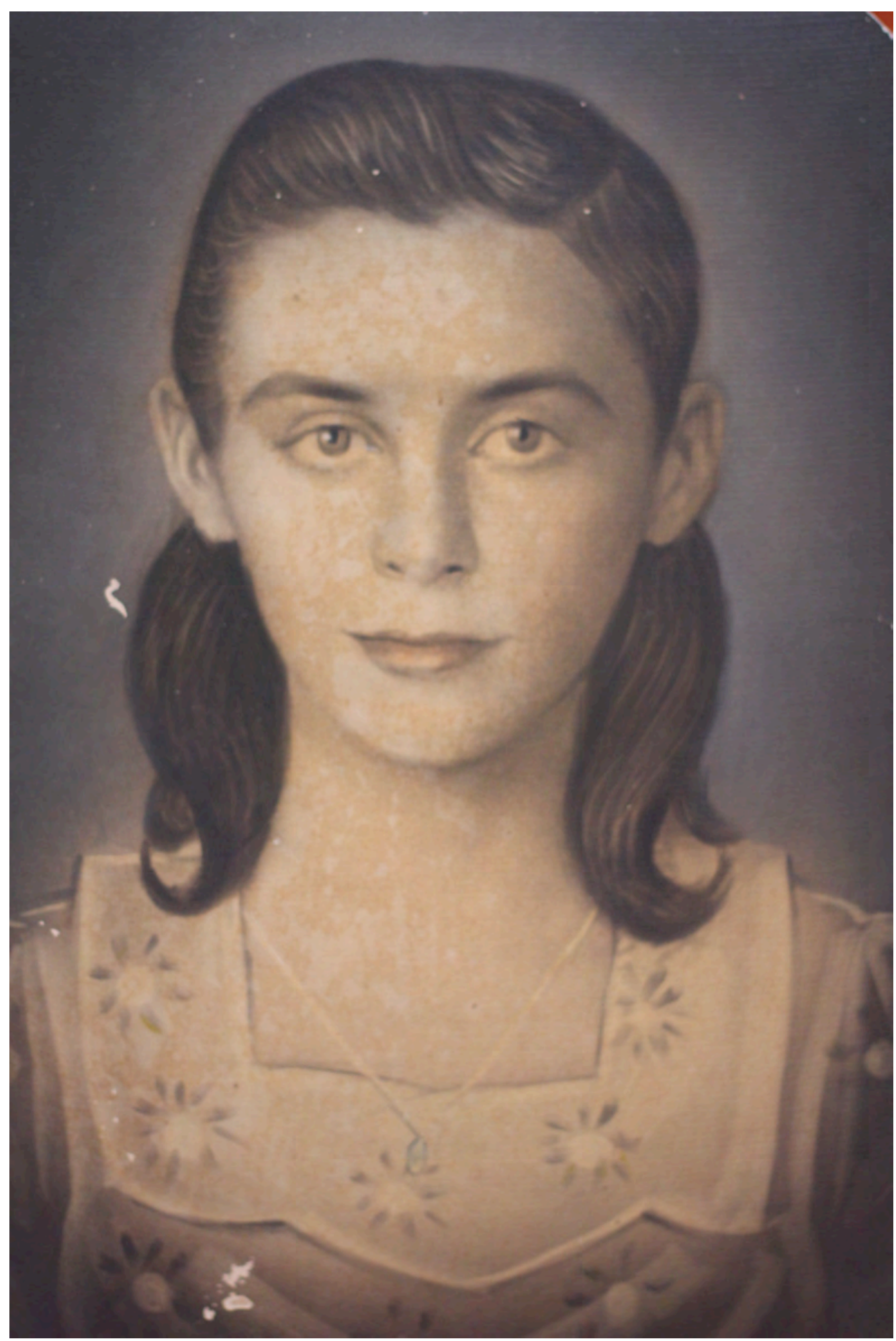


Da imagem que (me) falava: o retrato de minha avó materna. De la imagen que (me) hablaba: el retrato de mi abuela materna. Of the image that spoken (me): the portrait of my maternal grandmother.

https://dx.doi.org/10.17561/rtc.n16.2

\section{Da imagem que (me) falava: o} retrato de minha avó materna.

"Contar é muito dificultoso. Não pelos anos que já se passaram. Mas pela astúcia que tem certas coisas passadas de fazer balancê, de se remexerem dos lugares. A lembrança da vida da gente se guarda em trechos diversos, cada um com seu signo e sentimento, uns com os outros acho que não se misturam. Contar seguido, alinhavado, só mesmo sendo as coisas de rasa importância. De cada vivimento real que eu tive, de alegria ou pesar, cada vez daquela hoje vejo que eu era como se fosse diferente pessoa.

Sucedido desgovernado. Assim eu acho, assim é que eu conto" (ROSA, 1994, p.24).

Das minhas lembranças imagéticas afetivas a primeira que trago esculpida na memória é o retrado de minha avó materna Maria Elita.

Nunca cheguei a conhecê-la pessoalmente, mas desde cedo desenvolvi uma relação de grande afeto por ela, através de seu único retrato pintado à mão. Seus olhos me transmitiam serenidade apesar do mistério que envolvia sua aura. Era comum me pegar conversando com ela, querendo descobrir um pouco mais de si. O desejo de ter uma avó de verdade, para além do retrato, representava o desejo de ter o carinho e o aconchego do colo de uma grande, sábia e afetuosa mãe.

A vida negou-me uma avó, e uma mãe para minha mãe. Vovó Elita partiu aos 33 anos. Morreu no parto de outra menina, minha tia, também chamada Elita, nome dado por meu bisavô para homenageála, para torná-la viva e presente na vida da família. Essa outra Elita também não vingou, tornando-se anjo menina. Mais uma dor se abateu sobre a grande família materna. Esses fatos fizeram com que o nome delas fosse um enigma para mim.

Assim cresci, tendo minha avó materna sempre presente a me olhar através de um retrato colorido à mão. Uma avó plena, em imagem e corporificação, pois parecia conversar comigo sobre inúmeras coisas das quais pouco me lembro, ou nada. E eu acreditava na sua existência por meio do retrato. $E$ cresci sabendo de sua cor morena, de seu rosto e pescoço alongado; de seus cabelos lisos e escuros; de seus olhos castanhos; de seu semblante sereno; de sua simplicidade e beleza; de sua aura, misto de mistério e encantamento, revelação.

Uma coisa constantemente me inquietava neste retrato: a imagem que parou no tempo. O que fazia ecoar em mim uma perene pergunta: - Por que minha avó Elita permanecia mais jovem que minha mãe com o passar dos anos? Esse mesmo tempo me ajudou a responder.

Ao voltar-me agora para este retrato vejo a força do tempo deteriorá-lo, mas não a imagem de minha avó. Volto a ele como quem quer ampliar a imagem, compreender seus sentidos, $\mathrm{e}$ principalmente o de (re)encontrar a pessoa que nunca conheci, mas que permaneceu sempre presente, encarnada naquela fotografia. 
Para chegar a esses sentidos recorro à memória dos mais velhos: minha mãe Socorro, e meu tio Luizinho, filhos mais velhos de minha avó falecida; e meu tioavô Hilário, irmão de meu avô materno Duca, que era casado com minha avó Elita. As lembranças são poucas e fragmentadas. Quando minha avó morreu minha mãe tinha mais ou menos 11 anos, seu irmão uns 2 anos a menos, e meu tio-avô era um rapaz. Caso fosse viva hoje teria mais de 90 anos.

Segundo meu tio-avô Hilário, única testemunha viva de idade próxima a minha avó, ela era uma mulher magra, alegre e trabalhadora, morava na zona rural de Lavras da Mangabeira (Ceará, Brasil), e depois com a família constituída foi morar na cidade. Meus avós e tio-avô foram vizinhos alguns anos. Casas coladas pela mesma parede, construídas pelos dois irmãos. Tio Hilário era o irmão mais próximo de meu avô materno, está a caminho do 100 anos.

Meu tio Luizinho, filho de minha avó Elita, diz que ela possuía cabelos lisos e negros, pele morena, cor de jambo, estava sempre animada e gostava de cantar.

Minha mãe a descreve como uma mulher sempre bem-disposta, feliz, vaidosa, que gostava de cantarolar e era apaixonada pela vida, pelos filhos e por meu avô Duca. Numa passagem de sua breve vida mamãe relembra do gosto de vovó por anáguas para salientar sua cintura fina. Assim, costumava embebê-las numa mistura de água e goma, deixandoas descansar sobre um balaio grande de feira, para que ao secar ficassem bem armadas. Essas anáguas utilizadas por debaixo das saias ou vestidos rodados, tipo godê, ressaltavam sua silhueta delgada.

O impacto da morte de minha avó foi muito forte para minha mãe e seus irmãos. Como era a filha mais velha, e ainda criança, esse sentimento de perda se arrastou por toda sua vida, sendo repassado para nós seus filhos, atravessando gerações. Essa perda mudou o destino da vida de minha mãe, muitas escolhas suas foram determinadas por esta infeliz condição da ausência materna.

Nós filhos, fomos criados à sombra do retrato (meta)físico de minha avó, desenhado pelo imaginário de mamãe. Ele passou a representar a presença corpórea de minha avó em nossa casa e vida.

A memória imagética de minha mãe fez com que eu estabelecesse com o retrato de minha avó uma relação de cumplicidade.

Ao exercitar sua escrita poética, de verve popular, mamãe procura elaborar ludicamente essa perda, não deixando cair no esquecimento as poucas recordações de menina que guarda de sua mãe. Esses versos ajudam-me a entender de dor filial, ausências, perdas e saudades, ampliando poeticamente o retrato de minha vó Elita.

"Quantas lembranças chegando Agora em meu pensamento. Ideias vou arrumando, Registrando esse momento. 
Da imagem que (me) falava: o retrato de minha avó materna. De la imagen que (me) hablaba: el retrato de mi abuela materna. Of the image that spoken (me): the portrait of my maternal grandmother.

https://dx.doi.org/10.17561/rtc.n16.2

Com papai, mamãe viveu

Doze anos nesse mundo.

E depois ela morreu:

Nosso pesar foi profundo.

A oito filhos deu à luz

Com muito amor e doação.

Contou sempre com Jesus

Atuando na missão.

Morando no interior,

Sem nenhuma assistência,

Viu da morte o horror

Com bastante paciência.

Cedo ela foi percebendo

Da vida o desprazer.

Viu uma filha morrendo,

Ao terminar de nascer.

Alguns anos se passaram,

De novo veio a sofrer.

Os médicos não acertaram

E viu o Milton morrer.

A última filha que teve,

Ela não pôde curtir.

Chegou a hora derradeira

Pra deste mundo partir.

Pra uma mãe, perder um filho

É ver de perto a morte.

Na vida é sair do trilho,

Lamentando sua sorte.

Sofria mas se alegrava

Por qualquer coisa que havia.

Por tudo se motivava

Para fazer uma folia.

Quando o papai construiu

Casa nova pra morar,

Mamãe alegre sorriu:
Viu a vida melhorar.

Perto dos pais, bem contente,

Ela estava a residir.

E levava sempre a gente

Para os avós curtir.

Pouco tempo ela viveu

$\mathrm{Na}$ casa que esperou tanto.

A morte a surpreendeu

Deixando-nos num forte pranto.

Menos do que Jesus Cristo

$\mathrm{Na}$ terra mamãe viveu.

Na memória tenho escrito

$\mathrm{O}$ quanto ela sofreu.

Foi rápido o seu viver.

Não deu nem para curtir

Ver cada filho crescer

E encaminhar seu porvir.

Ah! Mamãe, quanta saudade

Sobrou pra mim neste mundo.

Quando vi que na verdade

Seu sono era profundo.

A vida pra mim sumiu.

Nem sabia o que fazer.

Ali, o sonho fugiu

Como o sol ao entardecer.

Irmãos menores que eu Junto ao meu pai a chorar.

Foi dor que muito doeu,

No meu peito a soluçar.

Neste mundo há muita dor.

De você sinto saudade.

Lembrando do seu amor,

Enfrento a realidade"

(PINTO, 2014, p. 18 - 20). 
Meu avô Duca depois de dois anos de falecimento de minha avó Maria Elita, casou-se com D. Maria Damiana, pessoa simples, sábia, generosa e muito bemhumorada, mas que jamais assumiria para nós o título de avó. Concretamente era nossa amada avó, representava bem este papel, mas o ícone de vovó Elita era muito forte, e seu retrato era presentificação dela em nossas vidas. Assim, D. Damiana recebeu o título carinhoso de "Madrinha" ou de "Vó Torta", este último termo, bastante usual no sertão nordestino brasileiro, serve para identificar uma senhora que foi adotada como avó de alguém. Uma avó não ligada por laços de sangue, mas por laços afetivos, no caso de Madrinha Maria laços muito fortes e felizes.

As lembranças de minha mãe, e dos meus tios, são agora as minhas lembranças e se concretizam em imagens. A mais forte e icônica de todas é a que descobri recentemente. Minha avó materna foi sepultada vestida de Nossa Senhora do Carmo. Como vovó Elita era devota desta santa, meu bisavô, seu pai, resolveu homenageá-la desta forma, encomendando sua filha à santa de sua devoção.

"Os trajes de santos sugerem um apelo à proteção dos mesmos, e sublinha a importância do cuidado com o cadáver na passagem para o além. Vestir-se de santo representava desejo de graça, imaginar-se perto de Deus, a roupa mortuária protegia os mortos e promovia uma integração bem aventurada" (REIS, 1995, p. 2).
Ao pedir a minha mãe que expressasse sua relação com o retrato de sua mãe percebo a grande ligação dela com a estampa. Apesar de ainda criança, quando vivenciou tal perda, ela consegue desenhar uma imagem mais extensa de sua mãe, situando-a num tempo/espaço social, econômico e político, revelando de maneira sutil detalhes estéticos e culturais. Assim, o singelo retrato de minha avó acaba por denunciar uma realidade histórica subjetiva e coletiva, que mesmo desgastada na memória insiste em perpetuar-se.

De repente dou-me conta de que a fotografia tem esse poder de congelar momentos e sentimentos, perenizando as pessoas e a paisagem de um tempo/espaço.

Estas informações sobre minha avó só chegaram até mim pela grande curiosidade que eu tinha sobre esse retrato, e através da insistente memória de minha mãe em querer apreendê-lo, tornando viva a fisionomia eternamente jovem de sua mãe.

"Esta é a foto da minha mãe. A única foto que ela deixou. Até hoje não encontrei outra. Mas não desisti ainda de procurar. Esta foto foi reproduzida de outra, que contém ela, papai e eu com talvez menos de dois anos de idade. Esta reprodução foi feita após a morte de mamãe, por uma das irmãs dela, não sei qual, e foi distribuída aos meus irmãos. Ao olhar esta foto, penso que minha vida e dos meus irmãos teria sido bem diferente com a presença dela entre nós. Ela era uma guerreira... Na época da minha mãe, as mulheres usavam umas anáguas, saias para vestir por baixo do vestido, 
Da imagem que (me) falava: o retrato de minha avó materna. De la imagen que (me) hablaba: el retrato de mi abuela materna. Of the image that spoken (me): the portrait of my maternal grandmother.

https://dx.doi.org/10.17561/rtc.n16.2

para a saia ficar bem armada. Teve uma época, início da década de 50 que as saias dos vestidos eram bem rodadas. Lembro de mamãe se arrumando com um destes vestidos de saia rodada, para participar com papai da festa de posse de Paulo Sarasate, quando ganhou a eleição para Governador do Estado do Ceará. A minha mãe era linda, linda! Muito alegre. Gostava muito de cantar: "Assum Preto", "Caboclo Marcolino", "Pedreiro Valdemar", "O Mancebo", "O ébrio", "Pequenina cruz do teu rosário", "Xote das meninas", "Casinha branca", "Alfaiate do $1^{\circ}$ ano", "Chofer de praça", "Sabiá (A todo mundo dou psiu)" e a música da Campanha do Governador Paulo Sarasate. Ela gostava de andar bem arrumadinha e com as unhas pintadas. Era muito organizada e gostava de tudo bem limpinho, e de todo trabalho bem feito" (Lembranças de minha mãe, suscitadas pelo único retrato de sua mãe, minha avó).

Sem o depoimento de mamãe, motivado por nossa conversa sobre a fotografia de sua mãe, talvez eu nunca soubesse dos gostos de vovó Elita pela moda, pelas cores, pela música popular, e seus posicionamentos políticos, mesmo que numa esfera limitada dada à condição feminina no tempo/espaço em que vivia. Digo isso porque era ela uma mulher que morava na zona rural e só depois de um tempo de casada passou a residir na pequena cidade de Lavras da Mangabeira, no interior do estado do Ceará, distante $440 \mathrm{~km}$ da capital Fortaleza.

Os gostos estéticos de vovó chegaram até mim como uma herança até então desconhecida. Desde pequeno descobri em mim uma habilidade para o desenho, e quando mais crescido gostava de fazer croquis de roupas para minhas irmãs, primas, tias e colegas da escola.

Ao tempo que crescia percebi que desenhar moda feminina despertava também o preconceito de algumas pessoas à volta, pela falta de informação. O medo da intolerância fez com que eu retraísse essa aptidão em mim, juntamente à falta de condições e estímulos para desenvolver tal capacidade. Somente mais tarde, quando adulto, formado em outra área, consegui fazer as pazes com o tempo, ao decidir cursar estilismo e moda numa escola profissionalizante em Recife, Pernambuco. A habilidade com a linha, a agulha e o tecido confirmou a herança da linhagem materna.

O gosto pela música de origem popular também foi um presente repassado de meus pais para nós, seus filhos. Com certeza uma tradição relembrada de nossos antepassados. Crescemos escutando e cantando músicas. Era um dos nossos passatempos favoritos nas longas viagens que fazíamos, pelas estradas, todos juntos nas férias, a caminho de Lavras da Mangabeira e Juazeiro do Norte para visitar nossa grande família parental. Algumas dessas músicas eram as que minha avó Elita gostava de cantarolar. Cantar, então, era também uma maneira de conhecê-la um pouco mais, vivendo em nós, para além de seu retrato.

Voltando ao retrato... Antes do acesso e popularização da fotografia colorida, era 
costume nas cidades do Cariri cearense retirar uma imagem de uma outra, e a partir dessa compor uma nova imagem mais cuidada, neste caso um retrato pintado ou fotopintura. Melhor dizendo, a partir de um recorte de um retrato em preto e branco ou em sépia encomendava-se uma cópia ampliada, colorida à mão. A confecção desse retrato envolvia um fazer artístico coletivo, que abarcava do vendedor, que passava de casa em casa à procura de clientes, até os artistas que estavam no estúdio a trabalhar os variados detalhes da fotografia encomendada.

Esses estúdios funcionavam como as antigas guildas de artistas da idade média, onde os quadros eram feitos com a contribuição de várias pessoas. Cada artista era especializado em uma parte específica do todo, compondo a completude da obra. Assim, haviam os responsáveis pelo rosto, pelos detalhes dos olhos e boca, pelos cabelos, outros pela indumentária, e outros ainda pela paisagem ou aura de fundo.

O retrato de minha avó materna, agora desbotado, também passou por esse processo, e trazia essa aura de encantamento própria dessa arte bastante popular, nos idos tempos de antes do advento da fotografia colorida.

Durante minha infância e adolescência esse retrato apresentou-se a mim como um ícone espiritual. A minha imaginação primeira fazia com que eu conversasse com a imagem, confessasse meus medos e anseios, meus segredos, angústias e dúvidas. Verdadeiramente eu sentia a presença de minha avó, ali a me orientar naquilo que me angustiava.
Coisas que um neto gostaria de partilhar, esperando um aconchego de uma mulher sábia e doce.

Desenvolvi em mim uma devoção aquele retrato. Com certeza a imagem que minha mãe fez de sua mãe, tanto mental como afetiva, ficou tatuada nessa fotografia.

No retrato abaixo, exponho o verdadeiro e único registro imagético da passagem de minha avó pelo mundo dos vivos. Foi dessa imagem que surgiu a outra primeiramente apresentada. Desde pequeno ela sempre foi um enigma para mim. No meu parco entendimento infantojuvenil acreditava que esta fotografia havia sido marcada com uma cruz para identificar que minha avó materna já havia falecido. É comum ao catolicismo a utilização de dois símbolos básicos para apontar o início e o fim do ciclo vital corpóreo: o nascimento recebe o código da estrela, e à morte cabe a cruz.

A cruz em si tanto representa a morte do corpo, como o renascimento para a vida espiritual. Estes símbolos estão presentes nas lápides dos cemitérios cristãos, das mais simples às mais rebuscadas Sobre esta fotografia, escuto minha mãe partilhar suas memórias, sentimentos e representações, querendo abraçar as pessoas em tempos que não vivi. 
Da imagem que (me) falava: o retrato de minha avó materna. De la imagen que (me) hablaba: el retrato de mi abuela materna. Of the image that spoken (me): the portrait of my maternal grandmother.

https://dx.doi.org/10.17561/rtc.n16.2

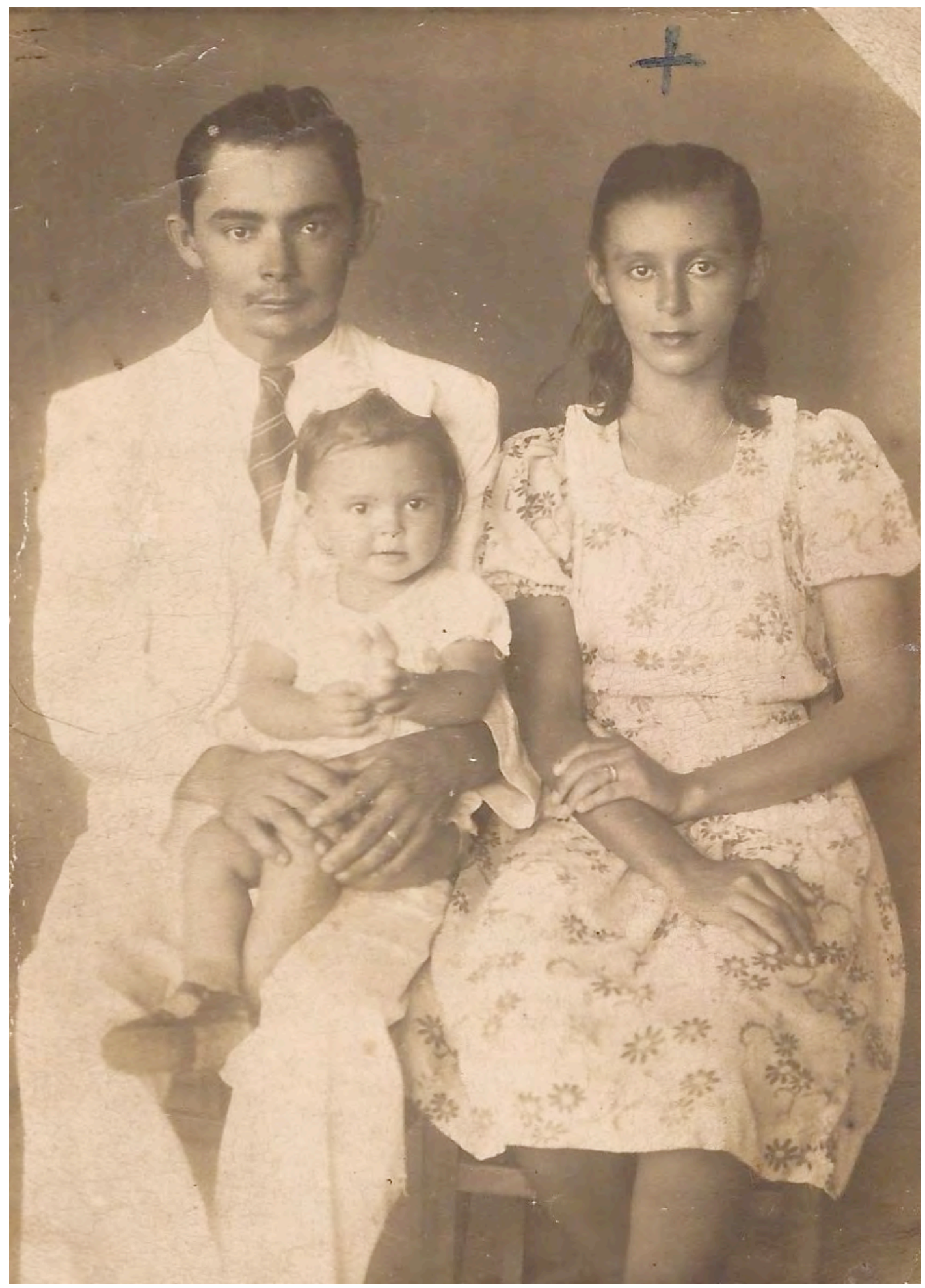


"Esta foto tem um significado muito importante para mim. É a única que contém ela. As outras são reproduções feitas a partir desta. Lembranças desta foto nenhuma. Nunca nem se quer ouvi mamãe dizer algo sobre a mesma. O dia a dia da minha mãe era tão cheio e o tempo que convivi com ela tão curto, 11 anos incompletos, passaram rápido demais. Sentimentos diversos me envolvem ao olhar para esta fotografia. Bate-me um desejo de vê-la e de tê-la junto a mim, e a vocês que não a conheceram. Mas que delírio! Volto a realidade e sinto-me feliz por ter concretizado o sonho que ela tinha de que eu estudasse, estudasse. Fui nos estudos até onde as minhas condições e opções de vida me permitiram. Tenho certeza que meu desejo de estar sempre aprendendo provém dela. Olhando para foto lembro da mulher alegre, trabalhadora, crítica, forte, imbatível, de pensamento positivo, muito organizada e muito cumpridora do dever. Mulher que sabia se cuidar e que tinha muito amor por si e pelos outros. Cuidava de tudo com muito esmero. Não tinha medo de dizer o que pensava e o que sentia. Olhando para a foto dela hoje, o meu maior desejo é poder reter na minha memória, gravar bem gravada na mente esta mulher, para nunca esquecer esta imagem linda, da mãe que tanto amo e amarei. Vejo meu pai ao lado dela, como alguém que estava pensando num futuro que estava se tornando realidade. Junto a quem ele amava. Vejo mamãe já tendo realizado seu desejo de ser mãe aos 21 anos. E devia estar muito contente em ver papai assumindo o fardo, segurando sua filha" (Minha mãe divagando sobre a fotografia de seus pais).
A menina da foto no colo de meu avó é minha mãe, que tinha no máximo dois anos de idade, quase 10 anos depois sua mãe faleceria. A relação de mamãe com essa fotografia fez distender o sentimento para o outro retrato de vovó Elita retirado daqui. E esse retrato novo, colorido à mão, teve grande influência sobre mim. Para mim, a presença metafísica de minha avó materna sempre pareceu-me mais forte que a presença física de meu avô materno. Ao tempo que crescia aprendi a admirar e me ver também nas características de minha avó, citadas por minha mãe.

Mesmo depois da partida corpórea de meu avô materno, no final da década dos anos de 1990, nunca foi marcada nesta fotografia uma cruz sobre sua cabeça. Pensava eu porque a marcação da cruz deveria estar à altura da última fotografia sua tirada em vida, a mais próxima do evento de sua morte.

Nos álbuns de fotografias de minha família nuclear, não consigo me recordar da existência de qualquer fotografia que tenha a presença de meu avô com a marcação de uma cruz. Achava estranho porque nesses álbuns há outras fotos antigas com esta marca, feita à caneta ou lápis. Acreditava eu que talvez fosse um costume antigo, abandonado com o tempo.

Passados muitos anos, para minha surpresa, conversando com mamãe sobre a imagem, descobri que a cruz que estava acima da cabeça de minha avó referia-se apenas a uma marca. Foi uma forma de mamãe garantir que aquela pessoa assinalada, deveria ser 
Da imagem que (me) falava: o retrato de minha avó materna. De la imagen que (me) hablaba: el retrato de mi abuela materna. Of the image that spoken (me): the portrait of my maternal grandmother.

https://dx.doi.org/10.17561/rtc.n16.2

representada no novo e maior retrato, recortado desse em que estava ela, minha avó e meu avô.

"Quando o vendedor passou lá em casa, quando morávamos em Juazeiro do Norte, levou a foto para ampliar. Para não haver dúvida na encomenda, marcou com esta cruz a foto de minha mãe. $\mathrm{Na}$ fotografia das três pessoas marcou só ela, para saber que aquele retrato era que deveria ser ampliado" (Minha mãe comentando sobre o retrato marcado com uma cruz, feita acima da cabeça de minha avó materna).

Após adulto também passei a admirar ainda mais o retrato de minha avó, e também esse outro que depois me chegou, dela com meu avô e minha mãe bebê, bem como as poucas lembranças que consegui compilar sobre sua breve história de vida.

Ao re(vi)ver essas imagens percebo que uma simples fotografia de um familiar pode reabrir uma janela poética descortinadora de temas sociais comuns a muitas outras pessoas e famílias. Histórias às vezes não contadas em seu tempo/espaço singular, capazes de reverberarem noutros tempos/espaços ampliados.

Essas imagens decalcadas na memória fazem-me (re)aproximar de minha família de outra forma e intensidade, já que há mais de 23 anos não vivo na mesma cidade que ela, e pouco partilho dos momentos coletivos e de minha subjetividade.
Quando me proponho discorrer sobre retratos de família abro um portal de redescobertas recheadas de memórias afetivas. Essas aproximações e achados, através do diálogo com familiares, referendam a importância e o sentido da pesquisa autobiográfica, que tem como mote a fotografia de família como catalisadora de vivências sociais e subjetivas.

Há tempos venho tentando decifrar o que algumas imagens dos álbuns de minha família representam para mim, porque acredito que elas invadem minha prática enquanto (arte)educador, (arte)terapeuta e (multi)artista, povoando de sentidos e referências afetivas minha produção criativa/cognitiva.

O desejo de confrontar-me com essas imagens, das quais muitas vieram antes de mim, colocam-me num desafio de observação e análise do antes, passado, e do depois, presente, ou ainda passado recente, dado que o tempo presente é impossível de ser captado pela fotografia. A fotografia é passado, e também mistério.

"Espelho mágico em que se conjugam o real e o imaginário, ponte entre $o$ presente e o passado, emblema, documento de identidade, é de uma memória subjetiva que as fotografias de família recebem seu valor e seu significado próprios. Fragmento do real que recorta o fluxo do tempo, toda foto é um registro parcial, uma pista para o trabalho da memória. Pista, toda foto encerra um mistério" (BARROS; STROZEMBERG, 1992, p. 80). 
Revista de Estudios en Sociedad, Artes y Gestión Cultural

ISSN: 2340-9096

https://dx.doi.org/10.17561/rtc.
http://revistaselectronicas.ujaen.es/index.php/RTC

www.terciocreciente.com
Número 16

Julio 2020

Investigación

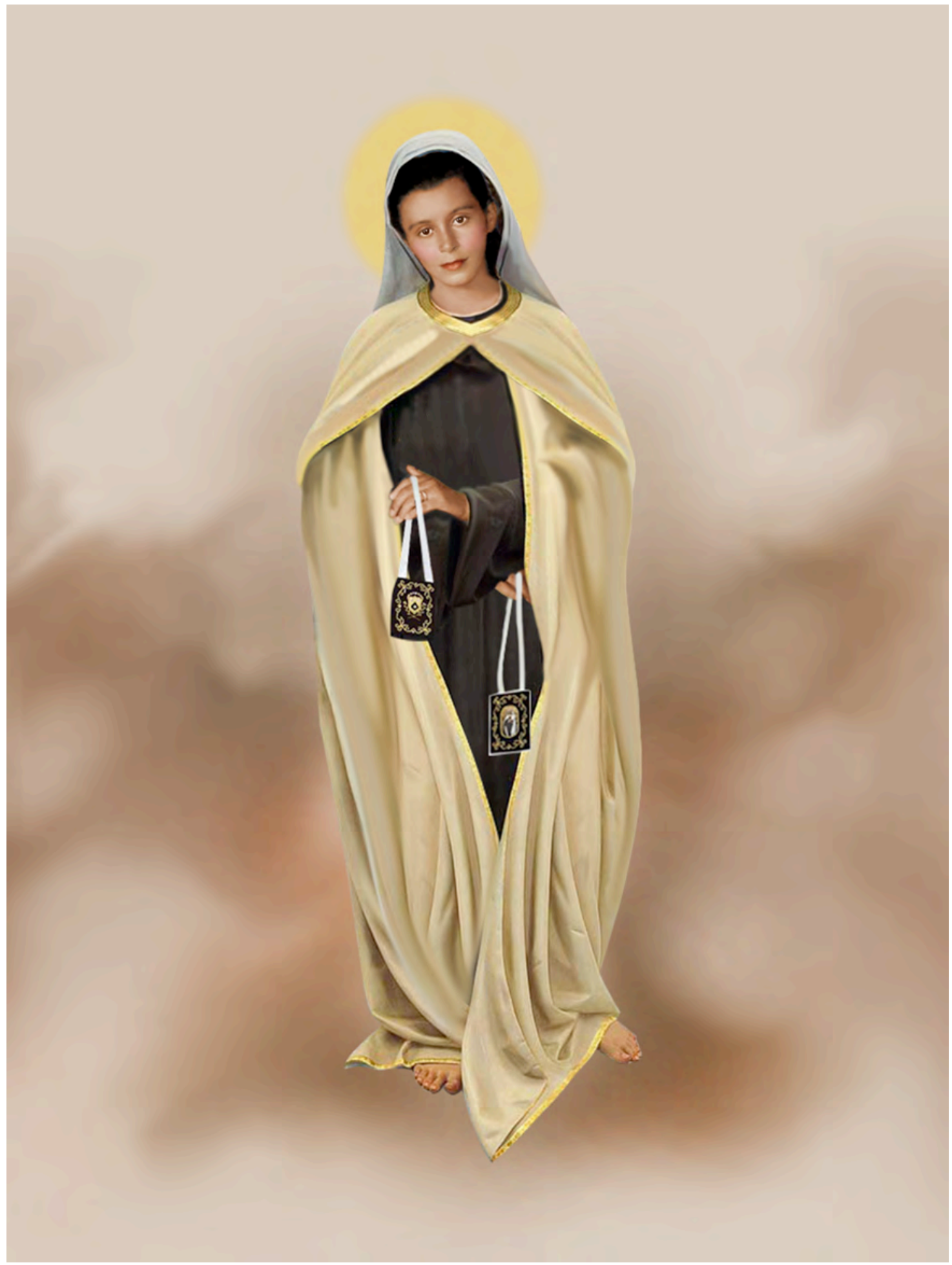


Da imagem que (me) falava: o retrato de minha avó materna. De la imagen que (me) hablaba: el retrato de mi abuela materna. Of the image that spoken (me): the portrait of my maternal grandmother.

https://dx.doi.org/10.17561/rtc.n16.2

Alimentado por esse passado e mistério, e também pelo imaginário infantil que se mantêm aceso em minhas buscas pessoais e profissionais, pedi ao amigo Mestre Júlio Santos, referência na fotopintura cearense, para compor uma imagem de minha avó Elita com as vestes de Nossa Senhora do Carmo, com a intenção de rememorar a maneira como foi vestida pelo meu bisavô materno, seu pai, quando do último registro corpóreo dela.

Mestre Júlio é um dos poucos artistas brasileiros vivo que trabalhou com a fotografía pintada à mão, no auge dos estúdios que empregravam várias pessoas para retocarem as imagens, originalmente confeccionadas em preto e branco, dando-lhes nova roupagem e vida.

Hoje, com o avanço da tecnología digital, este artifício foi abandonado, substituído pelos múltiplos recursos do "Photoshop". Mestre Júlio após resistências abraçou com amplo dominio este dispositivo e tem trabalhado continuamente com esmero na restauração de fotografías desgatadas pelo tempo, e na invetividade sobre os desejos das pessoas de se verem de outras formas.

$\mathrm{Na}$ fotomontagem digital, feita a partir do retrato original onde está minha avó, meu avô e minha mãe, aproveitou-se o rosto e os braços de vovó, que figuravam na velha imagen. A partir daí fez-se uma costura sincrética com uma estampa popular de Nossa Senhora do Carmo, que comumente é representada segurando o Menino Jesus em seus braços, mas nessa composição encomendada por mim a criança encontra-se ausente.

Nessa nova imagem minha avó surge segurando um escapulário, um externo sinal sagrado de devoção mariana, que consiste na representação de sua consagração à Santa Maria, por meio da Ordem Carmelita.

Ao agregar o rosto e braços de minha avó Elita à imagem da Santa, Mestre Júlio concede a minha avó a mesma condição de santidade. Principalmente porque na estampa a cabeça da Mãe de Deus está envolvida por uma auréola dourada. Além disso, ele põe minha avó suspensa, a levitar, em meio a nuvens de tons que combinam com a cor de suas vestes. Independente de qualquer figuração nova, para mim a imagem de minha avó revela-se como algo numinoso, intocável.

O mistério presente no antigo retrato do rosto de minha avó materna parece atravessar essa nova ilustração, perpetuando sua força. Seu olhar continua a me transpassar. Encaro esse olhar como uma provocação que me inquieta a responder com um maior interesse por outras fotografias que compõem os álbuns de minha família, pelos retratos guardados que me permitem o encontro com os que já se foram, com suas histórias de vida, assim encontrando-me também comigo mesmo e com minhas histórias de vida e finitude.

Esses encontros propiciam tirar do limbo registros subjetivos, e também coletivos, de afetividades escanteadas pela fugacidade das tecnologias e das 
Revista de Estudios en Sociedad, Artes y Gestión Cultural

ISSN: $2340-9096$

https://dx.doi.org/10.17561/rtc.
http://revistaselectronicas.ujaen.es/index.php/RTC

www.terciocreciente.com
Número 16

Julio 2020

Investigación relações humanas atuais. O papel impresso, frágil e concreto, traduzindo uma imagem familiar, é uma esperança perdida/achada em meio aos excessos de contemporaneidade. Ele é o espelho de nossa delicada e pretensiosa existência, e a fé de alguém que desejou ser lembrado, transpondo (i)materialidades fugazes, ansiando nos dizer algo... Impulsionando-nos a olhar nossas imagens pessoais, abraçando (re)existências mais felizes...
"Guardadas na permanente provisoriedade de caixas de sapato, as fotos incorporam uma missão e uma esperança: são mensagens para a posteridade, uma forma de fazer-se conhecer, não apenas para os contemporâneos, mas também para aqueles separados pelo espaço e pelo tempo, para aqueles já nascidos e para aqueles que ainda vão nascer" (KIM, 2003, p. 245-246). 
Da imagem que (me) falava: o retrato de minha avó materna. De la imagen que (me) hablaba: el retrato de mi abuela materna. Of the image that spoken (me): the portrait of my maternal grandmother.

https://dx.doi.org/10.17561/rtc.n16.2

\section{Referências}

BARROS, Myriam Moraes Lins de; STROZENBERG, llana. Álbum de família. Rio de Janeiro: Comunicação Contemporânea, 1992.

KIM, Joon Ho. A fotografia como projeto de memória. In: Cadernos de Antropologia e Imagem. 17 (2): 227-247. Rio de Janeiro: NAI/UERJ, 2003.

PINTO, M. Socorro M. No rastro da poesia. Fortaleza: Premius, 2014.

REIS, João José. A morte é uma festa: ritos fúnebres e revolta popular no Brasil do século XIX. São Paulo: Ed. Companhia das Letras, 1995.

ROSA, João GUIMARÃES. Grande sertão: veredas. Rio de Janeiro: Nova Fronteira, 1994. 